\title{
Effect of Some Antimicrobial Drugs on the Fitness of Honeybee Apis mellifera L. (Hymenoptera: Apidae)
}

\author{
Alshaimaa G. Alshafy ${ }^{1}$, Ehab W. Zidan ${ }^{1}$, Mohamed H. Rezk ${ }^{2,3}$, Wesam S. Meshrif ${ }^{2^{*}}$ \\ ${ }^{1}$ Bee Research Department Plant Protection Research Institute, ARC, Dokki, Giza, Egypt \\ ${ }^{2}$ Department of Zoology, Faculty of Science, Tanta University, Tanta, Egypt \\ ${ }^{3}$ Department of Biological Science, Faculty of Science and Humanity Studies at Al-Quwayiyah, \\ Shaqra University, Al-Quwayiyah 11971, Saudi Arabia
}

\begin{abstract}
Antimicrobial drugs are used by beekeepers to control bacterial and microsporidian infections. This raises concerns among individuals all over the world. The current work aims to determine the residue concentrations of three commonly used antibiotics (tylosin, sodium sulfademedin, and septazol) used to control honeybee infections, as well as to investigate the effects of antibiotics on bee biology. Honey was collected 42 days ( 2 generations of the worker development) posttreatment for HPLC analysis; honeybee activities (brood-rearing and pollen areas) were evaluated at 5 intervals every 12 days $(0,12,24,36$, and 48 days) post-treatment. Hygienic behavior and metabolic reserves (body proteins, lipids, and carbohydrates) were assessed at two intervals (0and 42-day) post-treatment. Results showed that residues of antimicrobial drugs in honey samples were significantly higher than those in the controls. Results indicated that no negative effect was observed on the brood rearing and pollen gathering as well as hygienic behavior of honeybee workers due to the doses of the antibiotics. Meanwhile, the colonies treated with tylosin showed lower hygienic behavior than the control at 0-day. The time progress did not affect the broodrearing area in all tested conditions. The metabolic reserves showed non-significant differences post-treatment compared with the controls. However, the body proteins and lipids exhibited lower contents at 42 days compared to those at 0-day. This study found a significant contamination risk for bee products as a result of inadequate apiculture techniques, as well as a possible risk to honeybees.
\end{abstract}

Keywords: Antibiotics, Bee activity; Honeybee fitness; Metabolic reserves.

\section{INTRODUCTION}

The honeybee Apis mellifera L. (Hymenoptera: Apidae) is the most important pollinator. Its colonies are globally used for the pollination of many crops and fruit grown in the open fields as well as numerous wildflowers (Klein et al., 2007, Blaauw and Isaacs, 2014). In addition, bee products are widely used as food, pharmaceutical drugs, and cosmetics (Zbuchea, 2017). Many interacting factors such as poor nutrition, parasites, pesticides, antibiotic exposure, climate changes, and habitat loss could cause colony decline (Alaux et al., 2010, Potts et al., 2016). Colony collapse disorder (CCD) was first reported in 2006 when the adult honeybees disappeared from the hives leaving behind a queen and a few nurse bees (Lee et al., 2015).

Sulfonamides and antibiotics are worldwide used in beekeeping to prevent or control honeybee diseases (Hansen and Brødsgaard, 1999, Williams, 2000). However, the abuse of these antimicrobials could leave residues in the beehive products. Some researchers found sulfonamides and tylosin residues in the honey (Zhang et al., 2019). Abd Alla (2020) also recorded several residues in the honey sample collected from different regions in Egypt. Antibiotic residues show a long half-life and they may have toxic effects on consumers or cause allergic reactions in hypersensitive individuals (Tillotson et al., 2006). The council regulation (EEC, 1990) and Egyptian Honey Specifications Standard (EOS, 2005) stated that the bee honey must not contain any antibiotic residues, i.e. no maximum residues limits'(MRLs). So that, it is desired to screen the presence of residues in bee honey after antimicrobial treatment by the beekeepers.

Hygienic behavior (HB) is an example of the social behavior of honey bees and a natural mechanism for the control of disease by removing dead brood (Lapidge et al., 2002). HB is an important behavior against the American and European foulbrood, and chalkbrood (Gilliam et al., 1983) and resistant mite, Varroa destructor, by removal infected pupae (Spivak, 1996). Some studies determined the level of HB for $A$. mellifera acarnica and A. mellifera jemenitica (Kamel et al., 2003, Balhareth et al., 2012). Woyke et al. (2012) observed that almost $89 \%$ of the freeze-killed brood was removed by the bees within $24 \mathrm{~h}$ while $95 \%$ of the pin-killed brood was removed within $48 \mathrm{~h}$ after introduction. However, HB was observed to decrease on exposure to oxalic acid (Bacandritsos et al., 2007).

Pollen quantity affects bees' physiology and immune competence (Field et al., 2002, Di Pasquale et al., 2013). Some studies observed a relation between the pollen area stored and the brood-rearing area (Standifer, 1980). Shortage of pollen area and broodrearing area affect the vigor of the colony and may cause colony decline or collapse (Neupane and Thapa, 2005). Fat bodies in bees, like the liver in humans, are responsible for energetic metabolism storage and conversion of protein, fat, and carbohydrates (Arrese and Soulages 2010). Abd El-Nabi et al. (2014) reported 
a high increase in the total proteins content and total carbohydrate with a diet supplement. Treatment of honeybee colonies with antibacterial such as Marjoram oil, oxalic acid, and tylosin caused a reduction of the worker hemolymph protein levels (Nafea et al., 2013). Other studies demonstrated a decrease in hemolymph protein, lipids, and carbohydrates after treatment with Bayvarol and Apivar (Bogaerts et al., 2009). Sometimes, these antibacterials may cause drops in carbohydrates and fat, while increasing proteins in the hemolymph after treatment with oxalic acid (Adjlane et al., 2013). In the current study, the presence of antimicrobial residues was screened in the bee honey following the common treatment used by the beekeepers, and the effects of these antimicrobials were evaluated on honeybee biology and physiology.

\section{MATERIALS AND METHODS}

\section{Honeybee and treatments}

This study was carried out at the apiary yard of the Bee Research Department, Plant Protection Research Institute, Dokki, Giza Governorate, Egypt from 18 June to 15 August 2020. The average density of bees per hive was approximately equal (at least seven combs covered with bees and headed by new mated carniolan hybrid queens). Twelve healthy hybrid carniolian honeybee colonies, Apis mellifera were divided into four groups: three treatments and one control; each with three replicates (colonies). Three antimicrobial drugs, tylosin, sodium sulfademedin, and septazol were used as well as the control. Control colonies were fed with (1:1) volume sugar solution.

\section{Antimicrobial Dosage}

Tylan ${ }^{\circledR}$ (tylosin tartrate; El Nassr Pharmaceuticals Chemicals Co, Cairo, Egypt) was applied as a suspension, which was prepared by dissolving $0.25 \mathrm{~g}$ tylosin in $500 \mathrm{ml}$ sugar solution (1:1) according to the Reybroeck method (2002). Suspension of sodium sulfademedin (sulfamethazin; Alexandria Pharmaceuticals \& Chemicals Industries Co, Alexandria, Egypt) was prepared by dispersing $0.75 \mathrm{~g}$ sodium sulfademedin in $500 \mathrm{ml}$ sugar solution (1:1). Sulfamethooxazol, trimethoprim; Alexandria Pharmaceuticals \& Chemicals Industries Co, Alexandria, Egypt) was used as a suspension by mixing $1 \mathrm{~mL}$ septazol with 500 $\mathrm{mL}$ sugar solution $(1: 1)$. These solutions were applied as food every four days/four times (Zidan, 2014). By the end of the application, this was set as 0-day. Controls were supplied with an equal amount of the same amount of food sugar solution (1:1) devoid of antimicrobial.

Samples were collected from all honey-bee colonies (honey and bee workers) at 0 - and 42-day (2 generations of the worker development) after the end of the application (12 days). This time frame (42 days) is supposed to be sufficient to reduce the antibiotic content of the honey harvested. The experiments were conducted in 3-6 biological replicates according to the experimental conditions.

\section{Determination of residual antibiotics (LC/MSMS)}

Honey samples were collected 42 days posttreatments for chemical analysis using Liquid Chromatography-Tandem Mass Spectrometry (LC/MSMS). Sulfamethazine and sulfamethooxazol were solubilized in methanol at a concentration of $0.5 \mathrm{mg} / \mathrm{l}$ and held at $20{ }^{\circ} \mathrm{C}$ until utilized, whereas tylosin standard was solubilized in water at a concentration of $1 \mathrm{mg} / \mathrm{ml}$.

Pure sunflower honey was provided by an Egyptian beekeeper, which was evaluated and used as a blank honey. Honey samples $(1.0 \pm 0.1 \mathrm{~g})$ were dissolved in a $0.5 \mathrm{ml}$ disodium hydrogen phosphate buffer solution (0.1 M, pH 8). Acetonitrile, the first extraction, was added to the sample and agitated for 10 minutes with a shaker (K-500, Janke \& Kunkel, Breisgau, Germany), then sonicated for 2 minutes with an ultrasonic bath (Branson 2510, Brandson Ultras-onics, Danburry, CT, USA). The mixture was centrifuged at $3632 \times \mathrm{g}$ (Mistral 2000, MSE Scientific Instrument, Crawley, UK) for 3 min at room temperature then collected into a new glass tube, dried under a stream of nitrogen at $45^{\circ} \mathrm{C}$ and stored at room temperature till used. Extraction No. 2 hydrolyzed sulfonamides in a water bath at $65^{\circ} \mathrm{C}$ for $1 \mathrm{~h}$, and then cooled at $4{ }^{\circ} \mathrm{C}$ for a few min. The mixture was neutralized by adding $120 \mathrm{ml}$ of $1 \mathrm{M}$ disodium hydrogen phosphate $(\mathrm{pH} 12)$. One $\mathrm{ml}$ acetonitrile was added to the hydrolyzed sample, shaken for $10 \mathrm{~min}$, and then sonicated, centrifuged, dried as above, and stored at room temperature till used.

The two dried extracts were individually suspended with $100 \mu \mathrm{L}$ of methanol/water $(20: 80$, v/v). After cautious vortexing and sonication, each honey extract was filtered through a $0.45 \mathrm{~mm}$ pored nylon filter (Nalgene, Rochester, NY, USA) directly into distinct HPLC vials and then stored at $-20{ }^{\circ} \mathrm{C}$ till analysis. Analysis was performed on an Agilent 1100 pump LC system coupled to a 4000 Q TRAP mass spectrometer instrument equipped with a turboboion spray ionization source. HPLC analysis was run on azorbax SB-C18 reverse-phase column $(2.1 \times 50 \mathrm{~mm}, 1.8 \mu \mathrm{m})$. The mobile phase was constituted with solvent A (water containing $1 \mathrm{Mm}$ NFPA mixed with $0.5 \%$ formic acid (v/v) and solvent B (acetonitrile/methanol (50:50, v/v) containing $0.5 \%$ formic acid $(\mathrm{v} / \mathrm{v})$.

The gradient program was $0 \min 0 \% \mathrm{~B}, 0-0.1 \mathrm{~min}$ $25 \% \mathrm{~B}, 0.1-3 \min 25 \% \mathrm{~B}, 3-7 \mathrm{~min} 80 \% \mathrm{~B}, 7-12 \min$ $95 \% \mathrm{~B}, 12-14 \mathrm{~min} 99 \% \mathrm{~B}, 14-15 \mathrm{~min} 0 \% \mathrm{~B}, 15-25 \mathrm{~min}$ $0 \% \mathrm{~B}$; running at a flow rate of $0.3 \mathrm{ml} / \mathrm{min}$ the injection volume was $10 \mu \mathrm{l}$ of each of the four honey extracts and was delivered into the High-performance liquid chromatography (HPLC) column. Quantitative analysis was performed using the most intense selected reaction monitoring (SRM) signal (SRM1) whereas the second SRM transition (SRM2) was used for analyte confirmation based on the appropriate area ratio calculated from the standard solution as described by Hammel et al. (2008). Data processing was performed using analyte 1:4:1 software Applied Biosystems MDS/SCIEX). 


\section{Measurements of brood area and pollen area}

The rearing areas occupied by unsealed and sealed worker brood and pollen area stored were measured using a frame divided into square inches on $0,12,24$, 36 , and 48 days post-treatment according to the method of Moosbeckhofer and Bretschko (1996). These measurements were performed in three biological replicates for each treatment along with the control.

\section{Hygienic behavior (HB) measurements}

An area (4-inch square equal 100 cells) of sealed worker brood was killed by piercing a thin metal pin into each cell and then the comb was returned to the hive to record $\mathrm{HB}$ according to the method of Sammataro (1996). The percentage of brood removal in each colony was recorded $24 \mathrm{~h}$ after piercing. These measurements were done two times at 0- and 42-day following antimicrobial treatment as well as in the control colonies. For each treatment and the control, this calculation was carried out in three biological replicates. Hygienic behavior was calculated according to the following equation:

$$
H B=\frac{(X-Y-Z)}{X} X 100
$$

Where $\mathrm{X}$ is the number of brood cells that were perforated and killed using a pin; $Y$, is the number of cells that remained capped, and $\mathrm{Z}$ is the number of uncapped cells with dead brood inside.

\section{Preparation of the honeybee body homogenate}

One honeybee worker approximately $(0.1 \pm 0.01 \mathrm{~g})$ weight was sterilized using $70 \%$ methanol solution and put in an Eppendorf tube with $0.5 \mathrm{ml}$ phosphatebuffered saline, PBS (0.1M, pH 7.8). Each sample was homogenized using fastgene ${ }^{\circledR}$ mixy homogenizer (NIPPON Genetics EUROPE GmbH, Dueren, Germany) for $10 \mathrm{~min}$ on ice and centrifuged (3-30KS, Sigma Laborzentrifugen $\mathrm{GmbH}$, Osterode am Harz, Germany) at $1000 \mathrm{xg}, 4^{\circ} \mathrm{C}$ for $10 \mathrm{~min}$. The supernatant is decanted into a new Eppendorf tube and kept till used at $-80^{\circ} \mathrm{C}$ ultra-freezer (Daihan Scientific, Korea) (Abd El-Nabi et al., 2014). This procedure was repeated 6 times (biological replicate) in each treatment and the control. Biochemical tests were conducted at the Department of Zoology, Faculty of Science, Tanta University.

\section{Determination of total protein, lipid, and carbo- hydrate contents}

The total body proteins were determined in the samples according to the colorimetric method described by Henry (1964) using a kit (Diamond®, Egypt). The sample and standard (albumin) were measured against a blank at $550 \mathrm{~nm}$ on a spectrophotometer (UNICO S1200, USA). The lipid content was also determined using the method of Zöllner and Kirsch (1962) at $540 \mathrm{~nm}$ against olive oil as a standard according to the instructions of the kit manufacturer (Biodiagnostics ${ }^{\circledR}$, Egypt).

The total carbohydrates were estimated according to the method described by Singh and Sinha (1977). The absorbance of samples and a series of strands glucose were measured at $620 \mathrm{~nm}$. This procedure was repeated
6 times per treatment. The total carbohydrates content was estimated using the equation of the regression line:

$$
\mathrm{Y}=0.096 \mathrm{X}+0.0074 \text {. }
$$

Where $\mathrm{Y}$ is the absorbance at $620 \mathrm{~nm}$ and $\mathrm{X}$ is carbohydrate concentration $(\mathrm{g} / \mathrm{dl})$.

\section{Statistical analysis}

Data were expressed as mean \pm standard deviation $(\mathrm{M} \pm \mathrm{SD})$. The effect of treatment with antibacterial drugs was investigated in the bee honey samples using an unpaired t-test. The level of significance was set on $p \leq 0.05, p \leq 0.01$ and $p \leq 0.001$. The effect of treatment on brood rearing and pollen areas was analyzed using regression with time elapsed. Two-way ANOVA was used to study the effect of treatment and antimicrobial type on HB and metabolic reserves. Multiple comparisons among the antimicrobials (Bonferroni) were used for in-depth analysis. These analyses have been done in GraphPad Prism version 8.0.0 for Windows, GraphPad Software, San Diego, California USA, www.graphpad.com".

\section{RESULTS}

\section{Residual concentration of antimicrobial drugs in bee honey samples}

Antibiotic residues (Tylosin, sodium sulfademedin, and septazol) used in honeybee treatment were detected in the honey produced. Figure (1) demonstrates the detected antibiotic used when the harvested bee honey samples were analysed using (LC/MS) MS after 42 days after treatment. In comparison to the control honey bee samples, treated bees in colonies after 42 days showed a higher concentration of antimicrobial drugs (Table 1). According to the results of t-test, the honey samples contained considerably higher tylosin $(\mathrm{t}=16.7, p \leq$ $0.001)$, sodium sulfamethazine $(\mathrm{t}=70.84, p \leq 0.001)$, sulfamethoxazol $(\mathrm{t}=8.25, p \leq 0.001)$, and trimthoprim $(\mathrm{t}=9.92, p \leq 0.001)$. Furthermore, the detected tylosin and sulfamethazine concentrations, in honey samples after 42 days of treatment, reached100-120 folds of Septazol.

Table (1): Residues of tylosin, sulfamethazine, and

\begin{tabular}{|c|c|c|}
\hline \multirow{3}{*}{ Antibiotic applied } & \multicolumn{2}{|c|}{ Residual concentration $(\mathrm{mg} / \mathrm{kg})$} \\
\hline & \multicolumn{2}{|c|}{$($ Mean \pm SD $)$} \\
\hline & Control & Treated \\
\hline Tylosin & $0.113 \pm 0.20$ & $13.880 \pm 1.415^{\text {**** }}$ \\
\hline Sulfamethazine & $0.008 \pm 0.02$ & $0.808 \pm 0.013^{* * *}$ \\
\hline $\begin{array}{l}\text { Septazol } \\
\text { (Sulfamethoxazol) }\end{array}$ & $0.088 \pm 0.08$ & $1.031 \pm 0.182^{* *}$ \\
\hline $\begin{array}{l}\text { Septazol } \\
\text { (Trimthoprim) }\end{array}$ & $0.032 \pm 0.02$ & $1.383 \pm 0.235^{* * *}$ \\
\hline
\end{tabular}
septazol in the honey after 42-day of treatment.

Other residues (Trimthoprim and sulfamethoxazol) reached to 43 and 12 fold in the honey. Generally, concentration of the residues in untreated or treated colonies is ascendingly arranged as tylosin $>$ trimthoprim > sulfamethoxazol > sulfamethazine. 

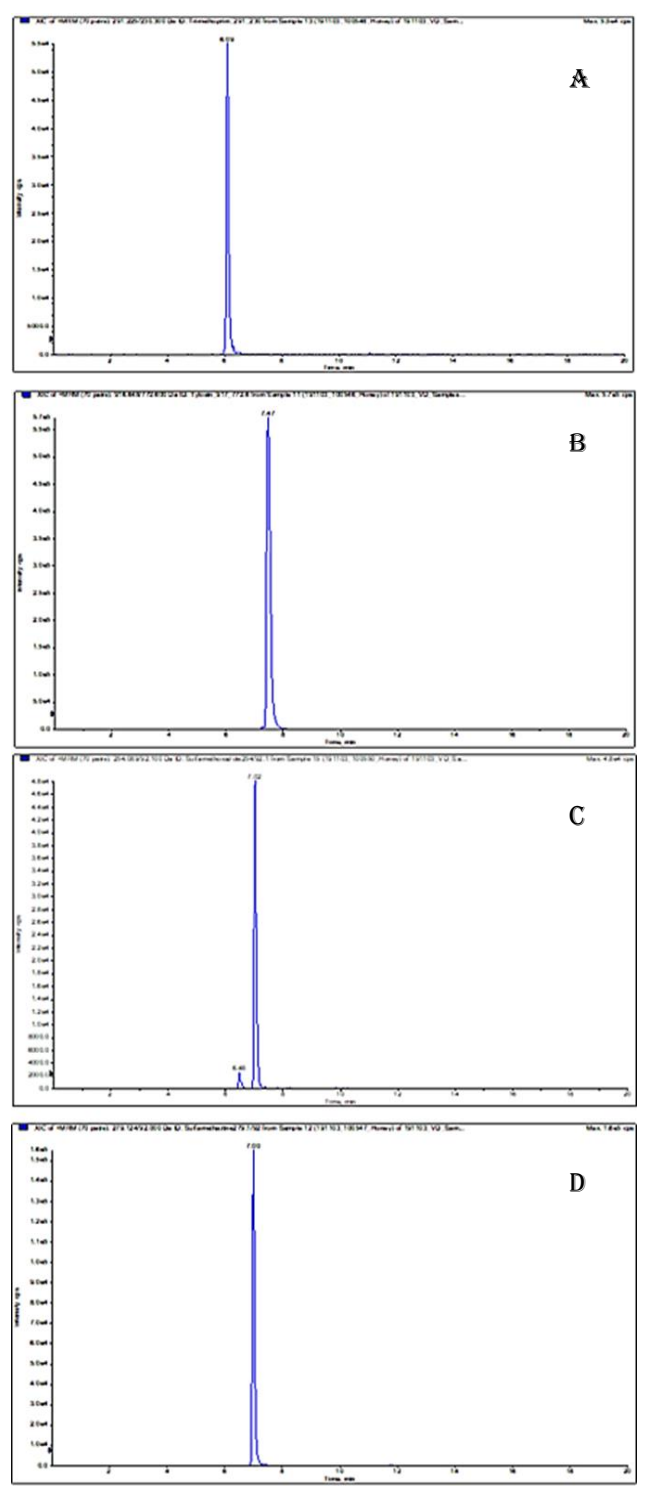

Figure (1):. Charts of LC-MSMS of trimthoprim (A), tylosin (B), sulfamethoxazol (C), and sulfamethazine (D) in the honey 42-day after treatment.

\section{Effect of antimicrobial drugs on the honeybee biology}

Effect of antimicrobial drugs on brood rearing and pollen stored areas

The effect of antimicrobial drugs on brood rearing activity is shown in Figure (2A). At 0-day, the broodrearing area was $342 \pm 38,213 \pm 57,377 \pm 22$, and 342 \pm 18 inch $^{2}(\mathrm{M} \pm \mathrm{SD})$ in the control and treated colonies with tylosin, Sodium sulfademedin, and septazol, respectively. ANOVA results at 0 -day indicated that treatment with tylosin recorded significantly lower $(p \leq$ $0.05)$ brood-rearing compared with all other treated groups. With time progress, the brood-rearing area indicated to follow a regression line equation: $\mathrm{Y}=$ $1.650 * \mathrm{X}+477.7, \mathrm{Y}=4.467 * \mathrm{X}+301.1, \mathrm{Y}=0.8056 * \mathrm{X}$ +412.0 and $Y=-1.256 * X+421.9$, in the control as well as the treated groups with tylosin, sodium sulfademedin and septazol, respectively. However, these lines are not significantly different from each other. Only tylosin was able to increase the broodrearing area with time progress in a significant way
$\left(\mathrm{F}_{1,13}=7.74, p \leq 0.05\right)$. The brood-rearing area in the control or treated with the remaining antimicrobial drugs showed no significant changes over time.

The effect of antimicrobial drugs on the pollen area stored is shown in Figure (2B). The pollen stored area at 0 -day was $221 \pm 24,293 \pm 32,193 \pm 27$, and $220 \pm$ 20 inch $^{2}$ (Mean \pm SD) in the control and colonies treated with tylosin, sodium sulfademedin, and Septazol. No significant differences were observed among these groups (ANOVA at 0-day). The regression analysis revealed that the pollen stored area in the control, treated colonies with tylosin, Sodium sulfademedin and septazol is inversely proportional to time increasing $(p \leq 0.001)$ according to the following equations: $\mathrm{Y}=-4.400 * \mathrm{X}+255.0, \mathrm{Y}=-4.511 * \mathrm{X}+$ 288.1, $\mathrm{Y}=-5.150 * \mathrm{X}+265.4$, and $\mathrm{Y}=-3.875 * \mathrm{X}+$ 220.8 , respectively. However, the treatment did not affect the slopes of these lines.

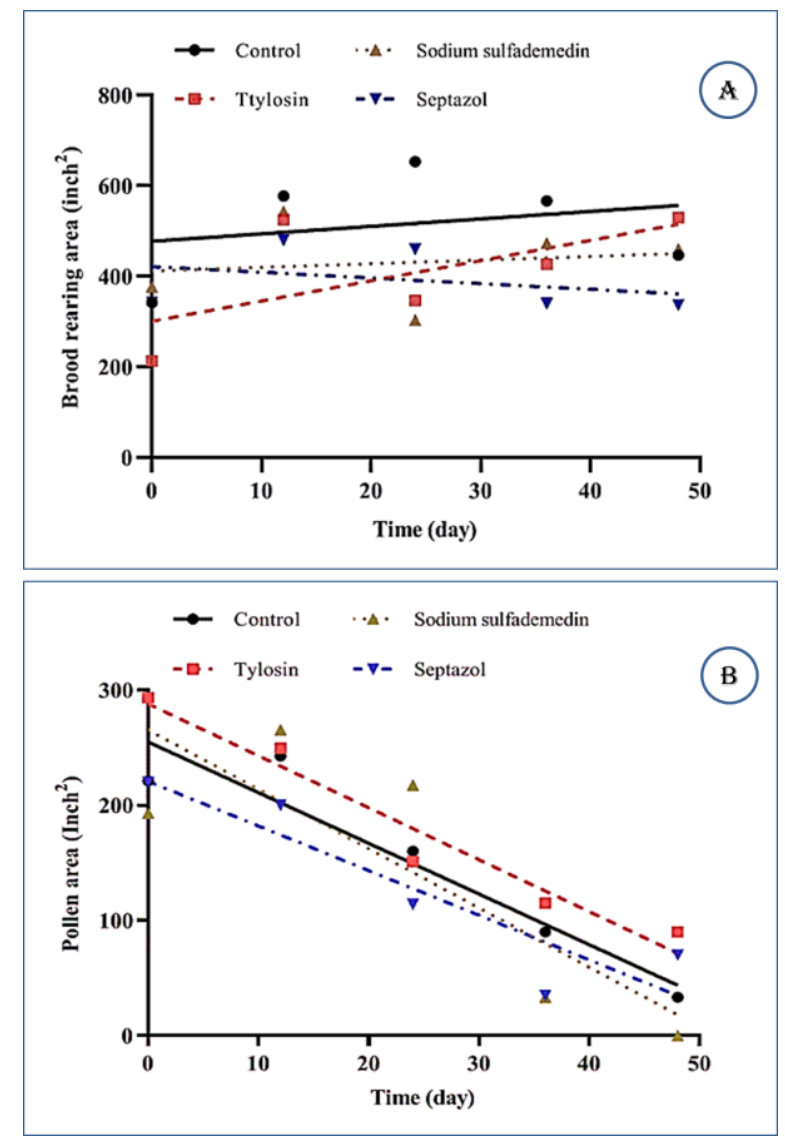

Figure (2): Regression of brood rearing area (A) and pollen area (B) by honeybee workers against time post-treatment with several antimicrobial drugs. $n=$ three biological replicates for each point.

\section{Effect of antimicrobial drugs on hygienic behavior}

The effect of antimicrobial drugs on the percentage of removed killed brood (\%) was summarized in Figure (3). Statistical Analysis (Two-way ANOVA) demonstrated that only time interval (42-day versus 0-day) affect the $\mathrm{HB}\left(\mathrm{F}_{1,8}=138.3, p \leq 0.001\right)$, whereas neither treatment nor the interaction affect it. The post-hoc analysis indicated that the $\mathrm{HB}$ at 42 days posttreatment was significantly $(p \leq 0.05)$ higher than those recorded at 0-day at all treatment. The Bonferroni's multiple comparisons between treatment means at 0 - 
day showed that the bees treated with tylosin had significantly lower $(p \leq 0.020)$ HB compared with the control. At 42 days post-treatment, no significant) difference has been observed between the means of HB (Figure 3).

Total reserved body reserves (protein, lipid, and carbohydrate contents)

Total body protein and lipid

The effects of antimicrobial treatments on total body protein and lipids are shown in Figures $4 \mathrm{~A}$ and $\mathrm{B}$. According to the results of the pairwise comparisons, only the time recoded a highly significant reduction in total body protein and lipid contents $\left(\mathrm{F}_{1,20}=136.7, p \leq\right.$ $0.001 ; \mathrm{F}_{1,20}=231.6, p \leq 0.001$, respectively), where, at 42 days post-treatment showed the lowest body protein and lipid contents. Neither treatment nor the interaction could affect the content of protein or lipid. Bonferroni multiple comparisons between the total protein or lipid content showed non-significant changes at 0 - or 42-day post-treatment.

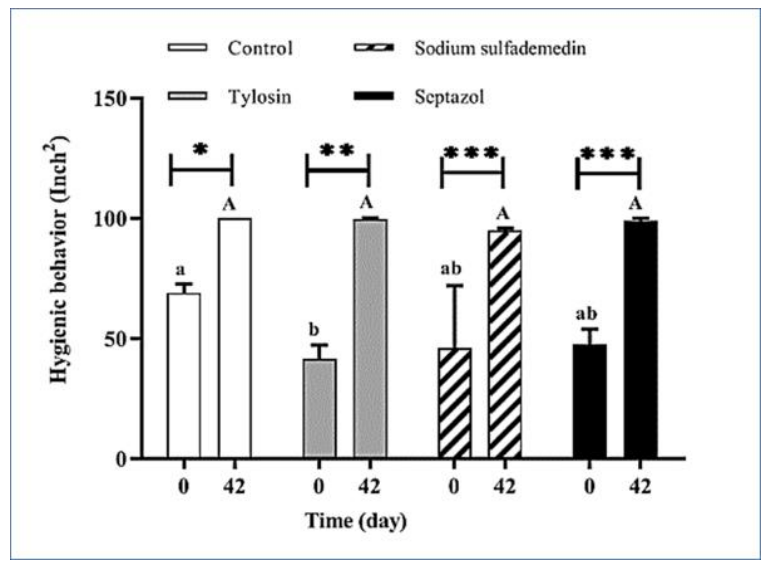

Figure (3): Hygienic behavior of the honeybee at 0- and 42-days post-treatment with tested antimicrobial drugs. Data are represented in mean $\pm \mathrm{SD}, n=$ three biological replicates per treatment. $*, * * \& * * *$ refer to significant differences at $p \leq 0.05$, 0.01 and $\leq 0.001$ level, respectively. Bars with the same letters within each time interval are not significantly different (Bonferroni's test).

Total body carbohydrate

The effects of antimicrobial therapies on total body carbohydrates are shown in Figures 4C, where no significant differences over time were recorded. On the other hand, Bonferroni's multiple comparisons between the body carbohydrates among different treatments at 0-day demonstrated that the honeybee treated with sodium sulfademedin had significantly lower carbohydrates than those treated with tylosin $(p \leq 0.05)$.

\section{DISCUSSION}

Antibiotics, commonly used in apiculture, influence honey quality, honeybee biology, and physiology (Ortiz-Alvarado et al., 2020). Overuse of antibiotics by beekeepers is considered to be among the reason for bees decline or CCD, which in turn affects the economy in different countries (Gallai et al. , 2009). Therefore, the current study addressed how antibiotic treatment commonly used affects the honey quality in terms of increased residues. The effect of these

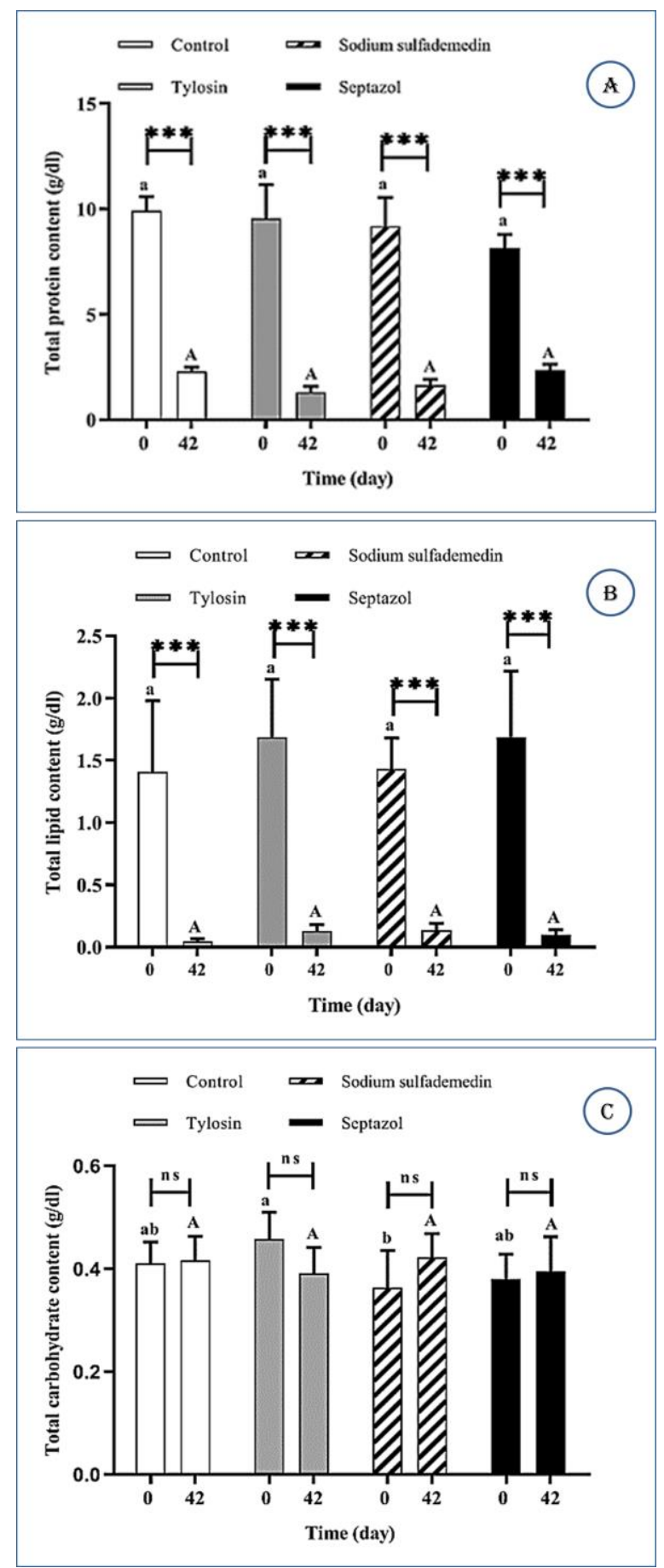

Figure (4): Total body reserves (g/dl) in honeybee workers posttreatment with tested antimicrobial drugs. Protein content (A); lipid content (B); and carbohydrate content (C). Data are represented in mean $\pm \mathrm{SD}, \mathrm{n}=$ three biological replicates per treatment. $* * *$ refer to significant differences at $p \leq 0.05,0.01$ and $\leq 0.001$ levels, respectively. Bars with the same letters within each time interval are not significantly different (ns) based on Bonferroni's test.

treatments on pollen area stored, brood-rearing area, $\mathrm{HB}$, and metabolic reserves in the carniolian honeybee, A. mellifera are observed.

In this study, tylosin, trimthoprim, sulfamethoxazol, and sulfamethazin residues were found to be higher than those in the control honey at 42 days ( 2 generations of the worker development) after dosing. the residues concentration detected were ascendingly arranged as tylosin > trimthoprim > sulfamethoxazol > sulfamethazine. The results of tylosin are slightly 
higher than those recorded by Adams et al. (2007) who found tylosin residues equal to $17 \mathrm{mg} / \mathrm{kg} 3$ days after dosing. In the control samples, the means recorded were $0.113,0.088$, and $0.008 \mathrm{mg} / \mathrm{kg}$ for tylosin, sulfamethoxazol, and sulfademedin respect-ively, These concentrations were consistent with those reported by Solomon et al. (2006) who analyzed 3855 samples and showed that tylosin residues were in the range $2-18 \mu \mathrm{g} / \mathrm{kg}$ and sulphonamid in the range 4.6-5 $\mu \mathrm{g} / \mathrm{kg}$.

In this study, all samples recorded higher values of the residues 42-day post-application. As a result, since the influence of antimicrobials tylosin, sodium sulfademedin, and septazol (understudy) on honey biology and metabolic reserves was observed, we recommend that beekeepers design a new approach for managing honeybee infections in Egypt.

The results obtained herein demonstrated that only tylosin was able to reduce the brood-rearing area and HB at 0-day. Tylosin has an acute effect on honeybee activity. This may reflect the stressful conditions or reduced vigor at this treatment as reported by Güler and Toy (2013). Bacandritsos et al. (2007) observed that HB decreased on exposure to oxalic acid. Ismail et al. (2006) recorded that treatments with eugenol reduced brood rearing activity. Moreover, Daisley et al. (2020) recorded a decrease in brood rearing after oxytetracycline application and showed a significant increase in brood count on adding LX3 select strains of 3 lactobacilli (Lactobacillus rhamnosus GR-1, Lactobacillus plantarum Lp39, and Lactobacillus kunkeei BR-1; LX3) to treated bees. Ortiz-Alvarado et al. (2020) observed that exposed bees to antibiotic treatment, induced a prolonged adiposity peak, stayed nurses, and delayed behavioral development into foragers (pollen collector). The results indicated that the $\mathrm{HB}$ at 42 days post-treatment was similar to the control value recorded. Abou-Shaara et al. (2013) reported that foraging activity is impacted by colony strength and brood-rearing activity. These investigations explain why pollen area stored decreased with time in treated groups. Keller et al. (2005) and Brodschneider and Crailsheim (2010) reported that pollen is not stored in large quantities and is used depending on floral resource availability and the colony's needs. At the end of the experiment, we noticed that tylosin induced an increase of brood rearing area with time elapsed. This may refer to the half-life time of tylosin residue within A. mellifera. The half-lives of tylosin in honey at $34{ }^{\circ} \mathrm{C}$ equal 130 days. Tylosin degraded to desmycosin in honey in mildly acidic conditions $\mathrm{pH}<4$ (Kochansky, 2004). Otherwise, the dosage of sodium sulfademedin and septazol could not affect the brood-rearing area in the treated honeybees.

Our results showed non-significant differences in total body protein, lipid, and carbohydrate among treatments. However, the total body protein and lipids were lower at 42 days than those at 0-time at all conditions tested. In agreement, Crailsheim (1990) recorded that level of protein varied with season and availability of food outside the hive. Feazel-Orr et al.2016) observed no effect on body weight, protein, and carbohydrate levels in treated bees with taufluvalinate. (Loucif-Ayad et al., 2010) observed reduced amounts of hemolymph protein, carbohydrate, and lipid in colonies treated with Bayvarol and Apivar, while no significant difference among colonies treated with Apiguard, ApiLifeVar and untreated colonies. Our results showed that treatment with sodium sulfademedin reduced the carbohydrates contents at 0-day compared with the control. Similarly, Adjlane et al.2013) reported that treatment with oxalic acid disrupted the metabolism of the bee.

\section{CONCLUSION}

According to this study, the common antibacterial dose employed by Egyptian beekeepers could result in a significant percentage of residues in honey. Except for tylosin, the same dose had no effect on the honeybee's brood area, pollen area, or HB. On total body proteins, lipids, and carbs, no additional impacts were seen. Future research should focus on the survival and immune competence of treated honeybees, particularly when a link to the gut microbiome is discovered.

\section{ACKNOWLEDGEMENTS}

The authors thank the staff members of the Central Laboratory of Residue Analysis of Pesticides and heavy metals in Food, Dokki, Giza, Egypt for the technical help to measure the antimicrobial drugs in the honey.

\section{REFERENCES}

ABD ALLA A.E. 2020. Research article residues of Tetracycline, Chloramphenicol and Tylosin antibiotics in the Egyptian bee honeys collected from different governorates. Pakistan Journal of Biological Sciences 23: 385-390.

ABD EL-NABI S.M. AND E.W. ZIDAN 2014. Activity Level of Lactate dehydrogenase and $\beta$ glucosidase Enzymes in the honeybee colonies, (Apis mellifera L.) with different feeding.Egypt. International Journal of Agricultural Technology 10(2): 483-491.

ABOU-SHAARA H.F., A.A. AL-GHAMDI AND A.A. MOHAMED 2013. Honey bee colonies performance enhance by newly modified beehives. Journal of Apicultural Science 57: 45-57.

ADAMS S.J., K. HEINRICH, M. HETMANSKI, R.J. FUSSELL, S. WILKINS, H.M. THOMPSON AND M. SHARMAN 2007. Study of the depletion of tylosin residues in honey extracted from treated honeybee (Apis mellifera) colonies and the effect of the shook swarm procedure. Apidologie 38: 315-322.

ADJLANE N., N. CHAHBAR, A. MAIDI, S. DOUMANDJI \& N. HADDAD 2013. Note scientifique sur les effets secondaires de l'acide oxalique sur l'abeille (Apis mellifera): aspect biochimique 
(Scientific note on side effects of oxalic acid on the worker bee (Apis mellifera): biochemical aspect). Journal of Materials and Environmental Science 4: 420-423.

ALAUX C., F. DUCLOZ, D. CRAUSER AND Y. LE CONTE 2010. Diet effects on honeybee immunocompetence. Biology Letters 6: 562-565.

ARRESE E.L. \& J.L. SOULAGES 2010. Insect fat body: energy, metabolism, and regulation. Annual Review of Entomology 55: 207-225.

BACANDRITSOS N., I. PAPANASTASIOU, C. SAITANIS, A. NANETTI AND E. ROINIOTI 2007. Efficacy of repeated trickle applications of oxalic acid in syrup for varroosis control in Apis mellifera: Influence of meteorological conditions and presence of brood. Veterinary Parasitology 148: 174-178.

BALHARETH H.M., A.S. ALQARNI AND A.A. OWAYSS 2012. Comparison of hygienic and grooming behaviors of indigenous and exotic honeybee (Apis mellifera) races in Central Saudi Arabia. International Journal of Agriculture and Biology 14: 1005-1008.

BLAAUW B.R. AND R. ISAACS 2014. Larger patches of diverse floral resources increase insect pollinator density, diversity, and their pollination of native wildflowers. Basic and Applied Ecology 15: 701-711.

BOGAERTS A., G. BAGGERMAN, E. VIERSTRAETE, L. SCHOOFS AND P. VERLEYEN 2009. The hemolymph proteome of the honeybee: Gel-based or gel-free? Proteomics 9: 3201-3208.

BRODSCHNEIDER R. AND K. CRAILSHEIM 2010. Nutrition and health in honey bees. Apidologie 41: 278-294.

CRAILSHEIM K. 1990. The protein balance of the honey bee worker. Apidologie 21: 417-429.

DAISLEY B.A., A.P. PITEK, J.A. CHMIEL, S. GIBBONS, A.M. CHERNYSHOVA, K.F. AL, K.M. FARAGALLA, J.P. BURTON, G.J. THOMPSON AND G. REID 2020. Lactobacillus spp. attenuate antibiotic-induced immune and microbiota dysregulation in honey bees. Communications Biology 3: 1-13.

DI PASQUALE G., M. SALIGNON, Y. LE CONTE, L.P. BELZUNCES, A. DECOURTYE, A. KRETZSCHMAR, S. SUCHAIL, J.-L. BRUNET AND C. ALAUX 2013. Influence of pollen nutrition on honey bee health: do pollen quality and diversity matter? PloS One 8: e72016.

EEC 1990. Council regulation (EEC) no 2377/90 of 26 June 1990 laying down a community procedure for the establishment of maximum residue limits of veterinary medicinal products in foodstuffs of animal origin. Official JL 224: 0001-0008.

EOS 2005. Bee honey and methods of analysis, Part 1. Egyptian Organization for Standardization and Quality Control. Cairo, Egypt.

FEAZEL-ORR H.K., K.M. CATALFAMO, C.C. BREWSTER, R.D. FELL, T.D. ANDERSON \& B.E. TRAVER 2016. Effects of pesticide treatments on nutrient levels in worker honey bees (Apis mellifera). Insects 7: 8 .

FIELD C.J., I.R. JOHNSON AND P.D. SCHLEY 2002. Nutrients and their role in host resistance to infection. Journal of Leukocyte Biology 71: 16-32.

GALLAI N., J.-M. SALLES, J. SETTELE AND B.E. VAISSIERE 2009. Economic valuation of the vulnerability of world agriculture confronted with pollinator decline. Ecological Economics 68: 810821.

GILLIAM M., III S. TABER AND G.V. RICHARDSON 1983. Hygienic behavior of honey bees in relation to chalkbrood disease. Apidologie 14: 2939.

GÜLER A. AND H. TOY 2013. Relationship between dead pupa removal and season and productivity of honey bee (Apis mellifera, Hymenoptera: Apidae) colonies. Turkish Journal of Veterinary and Animal Sciences 37: 462-467.

HAMMEL Y.A., R. MOHAMED, E. GREMAUD, M.H. LEBRETON AND P.A. GUY 2008. Multiscreening approach to monitor and quantify 42 antibiotic residues in honey by liquid chromatography-tandem mass spectrometry. Journal of Chromatography A 41177(1): 58-76.

HANSEN H. AND C. J. BRøDSGAARD 1999. American foulbrood: a review of its biology, diagnosis and control. Bee World 80: 5-23.

HENRY R.J. 1964. Clinical chemistry, principles and technics, New York, N.Y., Hoeber

ISMAIL A.M, H.A. GHONIEMY AND A.A.OWAYSS 2006. Combatting honeybee Varroa mites by plant oils alone or in an IPM program. The 2nd conference of Farm Integrated Pest Management 2006: 172-185.

KAMEL S.M., J.P. STRANGE AND W.S. SHEPPARD 2003. A scientific note on hygienic behavior in Apis mellifera lamarckii and A. m. carnica in Egypt. Apidologie 34: 189-190.

KELLER I., P. FLURI AND A. IMDORF 2005. Pollen nutrition and colony development in honey bees-Part II. Bee World 86: 27-34.

KLEIN A.-M., B.E. VAISSIERE, J.H. CANE, I. STEFFAN-DEWENTER, S.A. CUNNINGHAM, C. KREMEN AND T. TSCHARNTKE 2007. Importance of pollinators in changing landscapes for world crops. Proceedings of the Royal Society B: Biological Sciences 274: 303-313.

KOCHANSKY J. 2004. Degradation of tylosin residues in honey. Journal of Apicultural Rresearch 43: 65-68.

LAPIDGE K.L., B.P. OLDROYD AND M. SPIVAK 2002. Seven suggestive quantitative trait loci influence hygienic behavior of honey bees. Naturwissenschaften 89: 565-568.

LEE K.V., N. STEINHAUER, K. RENNICH, M.E. WILSON, D.R. TARPY, D.M. CARON, R. ROSE, K.S. DELAPLANE, K. BAYLIS AND E.J. LENGERICH 2015. A national survey of managed honey bee 2013-2014 annual colony losses in the USA. Apidologie 46: 292-305. 
LOUCIF-AYAD W., N. ARIBI, G. SMAGGHE AND N. SOLTANI 2010. A scientific note on the impact of acaracides on the nutritional biochemistry of Apis mellifera intermissa (Hymenoptera: Apidae). Apidologie 41: 135-137.

MOOSBECKHOFER R. AND J. BRETSCHKO 1996. Naturgemässe Bienenzucht, Graz Leopold Stocker.

NAFEA E., A. FATEHE, R. SANAD, S. ELMOHANDS, A. AZIEM AND E.W. ZIDAN 2013. Effect of honey bee therapy treatments on the protein levels of royal jelly and worker hemolymph. Journal of Plant Protection and Pathology 4: 457-462.

NEUPANE K. AND R. THAPA 2005. Alternative to off-season sugar supplement feeding of honeybees. Journal of the Institute of Agriculture and Animal Science 26: 77-81.

ORTIZ-ALVARADO Y., D.R. CLARK, C.J. VEGA-MELENDEZ, Z. FLORES-CRUZ, M.G. DOMINGEZ-BELLO AND T. GIRAY 2020. Antibiotics in hives and their effects on honey bee physiology and behavioral development. Biology Open 9: bio053884.

POTTS S.G., V. IMPERATRIZ-FONSECA, H.T. NGO, M.A. AIZEN, J.C. BIESMEIJER, V BREEZE, L.V. DICKS, L.A. GARIBALDI, R. HILL AND J. SETTELE 2016. Safeguarding pollinators and their values to human well-being. Nature 540: 220-229.

REYBROECK W. 2002. Residues of antibiotics and sulphonamides in honey on the Belgian market. APIACTA 38: 23-30.

SAMMATARO D. 1996. Mechanisms of bee resistance/tolerance to varroa mites. American bee journal (USA) 136: 567-568.

SINGH N. AND R. SINHA 1977. Carbohydrate, lipid and protein in the developmental stages of Sitophilus oryzae and S. granarius (Coleoptera: Curculionidae). Annals of the Entomological Society of America 70: 107-111.
SOLOMON R.J., V.S. SANTHI AND V. JAYARAJ 2006. Prevalence of antibiotics in nectar and honey in South Tamilnadu, India. Integrative Biosciences 10: 163-167.

SPIVAK M. 1996. Honey bee hygienic behavior and defense against Varroa jacobsoni. Apidologie 27: 245-260.

STANDIFER L. 1980. Honey bee nutrition and supplemental feeding. Beekeeping in the United States Agriculture Handbook, 335, 39-45.

TILLOTSON G.S., G.V. DOERN AND J.M. BLONDEAU 2006. Optimal antimicrobial therapy: the balance of potency and exposure. Expert Opinion on Investigational Drugs 15: 335 337.

WILLIAMS D. 2000. A veterinary approach to the European honey bee (Apis mellifera). The Veterinary Journal 160: 61-73.

WOYKE J., J. WILDE AND M. PHAINCHAROEN 2012. First evidence of hygienic behaviour in the dwarf honey bee Apis florea. Journal of Apicultural Research 51: 359-361.

ZBUCHEA A. 2017. Honey, Food and Medicine: Scientific Rationale and Practical Efficiency in External Administration of Medicinal Honey for Wound Healing. Journal of Agricultural Science and Technology 7: 206-219.

ZHANG Y., X.Q. LI, H.M. LI, Q.H. ZHANG, Y. GAO AND X.J. LI 2019. Antibiotic residues in honey: A review on analytical methods by liquid chromatography tandem mass spectrometry. TrAC Trends in Analytical Chemistry 110: 344-356.

ZIDAN E. 2014. Evaluation efficacy of certain antibiotics and essential oils for controlling the american foulbrood disease in honeybee colonies Apis mellifera L. Fayoum Journal of Agricultural Research \& Development 28.

ZöLLNER N. AND K. KIRSCH 1962. Colorimetric method for determination of total lipids. Journal of Experimental Medicine 135: 545-550. 


\title{
تأثير بعض المضادات الميكروبية على الكفاءة الحياتية لنحل العسل Apis mellifera (Hymenoptera: Apidae)
}

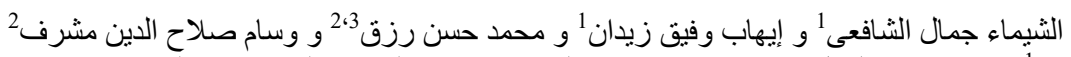

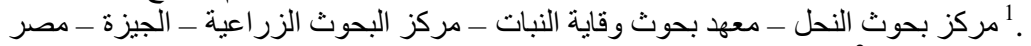

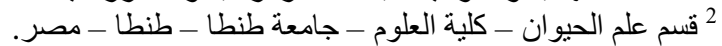

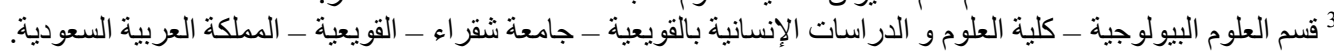

\section{الملخص العربـــي}

يستخدم النحالين عدد من المضادات الميكروبية في مكافحة الأمر اض البكتيرية و الفطرية فى نحل العسل. هذا يثير مخاوف حول العالم لما قد يكون له تاثير علي صحة الانسان. لذلك تهذف هذه الدراسة إلى تقييم التركيزات المتبقية لثناث من المضادات الميكروبية شائعة الاستخدام وهي التيلوزين و سلفاديميدين الصديوم و السييتازول التى تستخدم لعلاج أمر اض نحل العسل، وكذلك دراسة تأثير هذه العقاقير على بيولوجيا النحل. تم تجميع عينات من عسل النحل بعد (مدة جيلين من تطور الثغالة) 42 يوم من إنتهاء المعالجة للتحليل باستخدام HPLC، كما تم ملاحظة نشاطات النحل (مساحة تربية الحضنة و حبوب اللقاح) عند 5 فترات زمنية كل 12 يوم من انتهاء المعالجة. أما سلوك التنظيف والمخزونات الأيضية (بروتينات و دهون و كربو هيدر ات الجسم) فقد

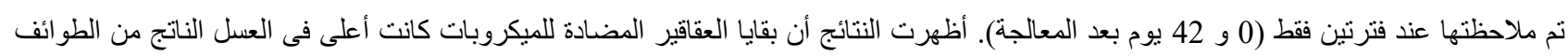

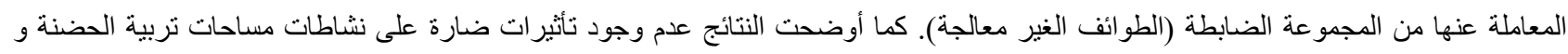
حبوب اللقاح و سلوك التنظف لنحل العسل المعامل بالجرعات المقررة. فى نفس الأثناء أظهرت المجموعة المعاملة بالتيلوزين إنحفاض فى سلوك التنظيف عن المجمو عة الضابطة عند الزمن (صفر) أى بعد 12 يوم من بدء العاملة. وكذللك فإن مرور الزمن لم يؤثر على مساحة تربية الحضنة بعد كل المعاملات.

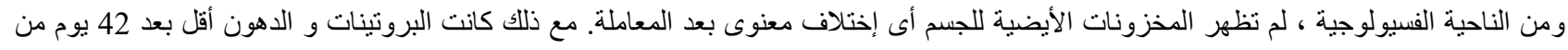

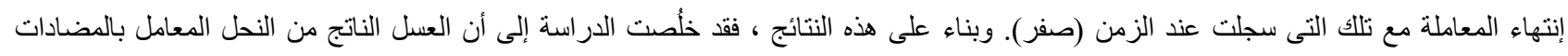
الميكروبية محل الدراسة إحتوى على خطر التلوث الناتج عن الممارسات الخاطئة للنحالين وكذا خطر محتمل على نحل العسل ذاته. 